\title{
Ethical management of limited medical resources in COVID-19 times
}

\author{
Manejo ético de los recursos médicos limitados en tiempos de COVID-19 \\ Ana Teresa Nez-Castro ${ }^{a}$, Arianna Omaña-Covarrubias ${ }^{b}$, Adrián Moya-Escalera ${ }^{c}$, Carlos \\ Cuevas-Suárez ${ }^{d}$, María del Refugio Acuña-Gorrola ${ }^{e}$
}

\begin{abstract}
:
The current COVID-19 pandemic has affected thousands of people around de world, regardless their race, religion, sexual preferences nor socioeconomic class, leaving all of us with the same vulnerability to suffer this disease. This emergency situation has shown to have the ability to collapse de health care systems in countries like: Italy, Spain, and the United States, because the medical personnel and the available material resources were exceeded. This conflict generates big ethical challenges for the practice of public health since difficult decisions have to be made about how, when and to whom the resources should be allocated. Due to the great responsibility that resource allocation implies, important points in the existing literature are exposed on how to give the best solution to this situation.
\end{abstract}

Keywords:

Medical resources, COVID-19, bioethics

\begin{abstract}
Resumen:
La actual pandemia generada por la enfermedad por coronavirus (COVID-19) ha afectado a miles de personas alrededor del mundo, sin hacer distinción de raza, religión, preferencia sexual o clase socio-económica, dejándonos a todos igual de vulnerables a padecer dicha enfermedad. Esta situación de emergencia ha mostrado tener la capacidad de colapsar los sistemas sanitarios en países como Italia, España y Estados Unidos, pues el personal médico y los recursos materiales disponibles fueron superados, este conflicto genera grandes desafíos éticos para la práctica de la salud pública ya que se requiere de la toma de decisiones difíciles sobre cómo, cuándo y a quién le deben ser asignados los recursos. Debido a la gran responsabilidad que implica dicha asignación de recurs os, se exponen puntos principales de la literatura existente sobre cómo dar la mejor solución a tal situación.
\end{abstract}

\section{Palabras Clave:}

Recursos médicos, COVID-19, bioética

\section{INTRODUCTION}

The coronavirus disease (COVID-19) started in the city of Wuhan, China at the end of 2019 (Zhang, 2020) and for March 11,2020 , at a discourse given by the General Director of the World Health Organization (WHO), he declared this disease as a pandemic since the number of cases had multiplied by 13 and the number of affected countries had tripled ((WHO) O. M., 2020).
But, what does a pandemic imply? According to the Royal Spanish Academy, the pandemic is defined as an epidemic extended to many countries or that it attacks almost every individual of a place or region ((RAE), 2019), which implies that COVID-19 makes no distinction of race nor class, make us all vulnerable to the disease. This fact is reflected today since COVID-19 has taken more than 322 thousand lives around the world; while in Mexico, according to numbers reported by the ministry of prevention and promotion of health, there are more than 5,000 deaths and more than 167 in

\footnotetext{
"Estudiante Maestría en Nutrición Clínica. Instituto Ciencias de la Salud. Universidad Autónoma del Estado de Hidalgo,

b Autor de Correspondencia, Profesor Área Académica de Nutrición. Instituto Ciencias de la Salud. Universidad Autónoma del Estado de Hidalgo, Instituto de Ciencias de la Salud, ORCID: 0000-0002-8649-8617, Email: aomana@uaeh.edu.mx

Profesor Área Académica de Medicina. Instituto Ciencias de la Salud. Universidad Autónoma del Estado de Hidalgo, Instituto de

Ciencias de la Salud, ORCID: 0000-0003-4448-2883,Email: amoya@uaeh.edu.mx

d Profesor Área Académica de Odontología. Instituto Ciencias de la Salud. Universidad Autónoma del Estado de Hidalgo, Instituto de

Ciencias de la Salud, ORCID: 0000-0002-2759-8984,Email: carlosecsuarez@ gmail.com

e Profesor Área Académica de Gerontología. Instituto Ciencias de la Salud. Universidad Autónoma del Estado de Hidalgo, Instituto de

Ciencias de la Salud, ORCID: 0000-0003-3194-5392, Email: madereag@gmail.com
} 
the state of Hidalgo, according to the State's government, these numbers are still increasing.

The high number of deaths cannot be compared to the number of infected people who are fighting for their lives in hospitals, number that continues increasing day by day and that has the capacity to collapse the health care systems in countries like Italy, Spain, and the United States (Trilla, 2020), since the health care staff and the available resources were exceeded. This situation generates great challenges for the practice of public health because difficult decisions have to be made about how, when and to whom these resources must be allocated.

\section{BIOETHICAL ORIENTATION IN THE MANAGEMENT OF LIMITED RESOURCES DUE TO AN INCREASE IN THE NUMBER OF COVID-19 CASES}

For the medical practice during an emergency situation like the pandemic caused by SARS-Cov2 virus, the main objectives of attention should be: 1) to treat the largest number of patients and 2) to safe the largest amount of lives possible, according to the available resources. To provide this attention, it is required to conduct an evaluation of the survival probability of the patient and the time the patient will need the resources ((CSG), 2020). Nevertheless, the insufficient medical resources generates uncertainty about the right way to allocate those resources when two or more patients need them.

Although, ethical dilemmas have no correct answer, the problem of these decisions took several physicians to look for ethical counseling; and due to the great responsibility this implies, there is a lot of literature on how to give the best solution to this situation.

It is important to mention that the resources that might get scarce are divided into two: divisible resources, which are those that can be segmented and therefore distributed a larger number of patients; on the other hand, there are the indivisible resources, which by nature cannot be segmented, limiting their use to one patient only. These las tones are those that must be allocated ((CSG), 2020).

\section{TRIAGE IN COVID-19 CASES}

The triage is a selection and classification system of patients in the emergency services, based on the therapeutic needs and the available resources. This allows to manage the clinical risk to optimize the attention and safety of people. It is the access door to an efficient attention, therefore, a quick and easy tool to apply, that also has a strong predictive value of seriousness, evolution and use of the resources. The classification is carried out in many environments, including emergencies and disasters, during incidents with massive victims and for a proper classification in the emergency department. The purpose is to quickly classify patients who need immediate or differentiated attention from those who can wait a safe evaluation and treatment.

An important detection point of COVID-19 cases is the hospital emergency department where the triage aims at identifying and prioritizing the most serious patient and quickly implement the measures of infection control necessary for each case. In the current context, it is prioritized the quick identification of each suspect and the implementation of measures that help minimizing the spreading of SARS-CoV2.

The current literature suggests different approaches such as the non-existent vital signs or a detection tool in triage: Identify, Isolate and Inform. The non-existent vital signs refer to the need of doing a quick detection of situations of epidemic risk before going checking the vital signs in the triage. The "detection took in triage: Identify - Isolate -Inform" provides a quick glance on how to tackle these cases from triage.

Before admitting the patient into the corresponding health care institutions, a timely triage must be done (Solerno, y otros, 2020), which evaluates the seriousness of the disease in order to determine the need to use hospital supplies or determine the probability of survival allowing a timely approach of the patient (Rodríguez-Morales, et al., 2020), as shown in Table 1.

Table 1. Triage in COVID-19 cases*

\begin{tabular}{|c|c|c|}
\hline $\begin{array}{ll}\text { Type } & \text { of } \\
\text { patient }\end{array}$ & Reference & Treatment \\
\hline $\begin{array}{l}\text { Healthy, with } \\
\text { no respiratory } \\
\text { symptoms }\end{array}$ & Home & $\begin{array}{l}\text { Infection } \\
\text { control } \\
\text { measures }\end{array}$ \\
\hline $\begin{array}{l}\text { Respiratory } \\
\text { Symptoms not } \\
\text { compatible }\end{array}$ & Home & $\begin{array}{l}\text { Symptomatic } \\
\text { and infection } \\
\text { control }\end{array}$ \\
\hline $\begin{array}{l}\text { with COVID- } \\
19\end{array}$ & & \\
\hline $\begin{array}{l}\text { Suspicious } \\
\text { case of } \\
\text { COVID-19 } \\
\text { with no added } \\
\text { chronic } \\
\text { disease, it is } \\
\text { not a high risk }\end{array}$ & $\begin{array}{l}\text { Strict home } \\
\text { isolation }\end{array}$ & $\begin{array}{l}\text { Symptomatic } \\
\text { and infection } \\
\text { control }\end{array}$ \\
\hline
\end{tabular}




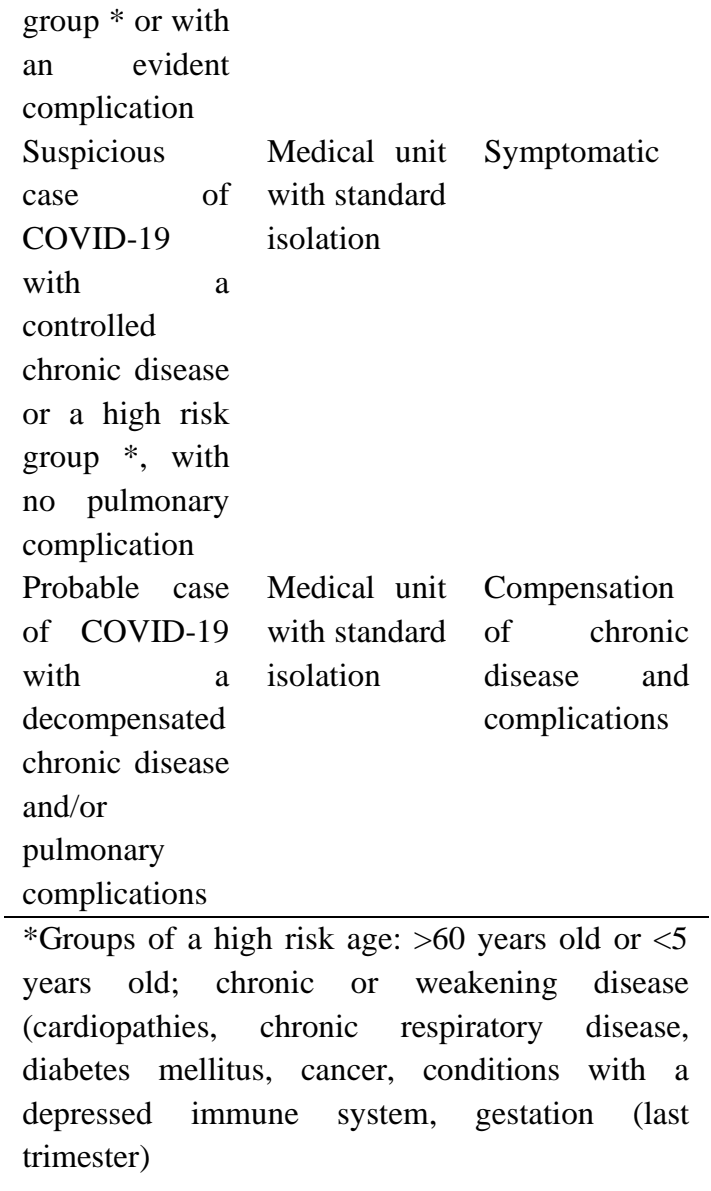

* Taken from Rodríguez-Morales, et al., 2020.

It is important to mention that the team who provides medical attention to patients, must be completely different from the team in charge of doing the triage and should be formed by:

- First responsible: physician specialist in intensive care, emergency medicine, pneumology, internal medicine or other similar.

- Second responsible: medicine professional or intensive nursing, emergency medicine, pneumology or other related.

- Manager: the manager of a hospital unit ((CSG), 2020).

Besides, the decisions taken by the triage must be regularly supervised by a local committee who will guarantee equality; and finally, the classification method must be regularly reviewed based on the evolution of the knowledge about the disease (Rosenbaun, 2020).

\section{CLASSIFICATION OF ETHICAL PRINCIPLES FOR THE ALLOCATION OF SCARCE RESOURCES}

According to Emanuel et al., four categories can be established based on their ethical value and always with the objective of providing an equal attention and prioritizing the most serious cases.

\section{Equal treatment}

To benefit the people equally, so everyone has the same opportunity to access to the required medical intervention. This can be determined through a random allocation where it is established that the first one to arrive will be the first one to be attended. This can give the same opportunity to access to the medical service but it might not consider the severity of the condition.

\section{Favoring vulnerable groups}

The vulnerability and social inequality are highly relevant topics for social research, due to their intensity and persistence, as well as the inefficacy of the actions for its decreasing/overcoming. The phenomena associated with the disadvantages that certain groups live constitute a central point to understand the mechanisms of social reproduction, particularly because they allow to explore and demonstrate the specific mechanisms of the different ways of social organization.

While there are highly complex tools to measure (establishing levels) the amount, the intensity, and the incidence of these conditions, under concepts of poverty, social exclusion, marginality, and vulnerability, it is necessary to analyze with other tools of social research the experiences of individuals situated in a given space and time to understand how they express and live.

Vulnerability is in each and everyone of us, as there are other human characteristics like consciousness and the capacity to love, the empathy and the will to survive. No one can scape from it. There is no one who is not vulnerable. Therefore, every human being is vulnerable since it is an intrinsic characteristic of our mortal nature. Vulnerability must not be approached as a negative thing since it shows our capacity of reacting, resisting and recover from a wound or a physical or moral injury.

Regarding the protection of human rights, the notions of equality and vulnerability are particularly linked. Those who, for different reasons, have diminished capacities to face possible violations to their human rights, are considered vulnerable. Those diminished capacities that vulnerability is associated with a condition that allows identifying a person as part of a group that, as a general rule, is clearly under conditions of inequality regarding a larger group.

Therefore, five vulnerable groups have been identified and it was considered particularly relevant to study them. Those five are: woman, kid and adolescent, LGTB, disabled, traditional towns, and African descendants. Regardless of others, we have focused on these ones for considering them particularly interesting and because the vulnerability situation they suffer 
from has an impact on social cohesion, generating material inequalities at the core of our societies.

The degree of people's vulnerability depends on several physical, economic, and political factors, but measures that mitigate the effect of these factors can be applied, this means that measures to reduce the danger effects of human rights violations can be applied. Among these measures there is the development of alerts before violations and the preparation to face them, but also the development of skills to recover from those violations and resist them, and in this field, human rights are extremely important.

The assistance of vulnerable groups can be based on the principles of "The patient first", which gives priority to the patient whose health state is more compromised if he/she does not receive a timely attention, because there are some who have the possibility of recover without treatment or receive it late; and "The young people first", where the resources are allocated to those with more life expectancy, but it turns insufficient because the prognosis is not considered after the treatment, so it is recommended to use it together with a random distribution.

\section{Maximization of the benefit}

One of the maximization strategies refers to save as many lives as possible, since every life has the same value and it does not consider the fact that there are shorter lives than others, although this is not always the most efficient principle. Other principle under maximization of the benefit and different from the previous point is based on the lifeexpectancy by depending on the main idea of: "living more years is worthy and therefore, saving more years of life is worthy as well".

\section{Social use or reward}

This category suggests that the allocation must prioritize the social value of specific individuals, who promote important values or reward them for having carried out this action, this means that this is based on prioritizing those individuals not for having a value, but for the benefit they can give to others, as it is the case of the essential health care personnel. Or it even implies a reciprocity action by rewarding those who gave a service, a benefit or even those who made sacrifices for a greater good, for example, for the researchers who work in the development of vaccines, health care staff or even volunteers who have been involved in risky tasks that benefit the community (Emanuel, Persand, Upshur, Thome, \& al, 2020).

Patients who were not provided with medical resources or to whom these resources have been taken away, must receive a support treatment, or if necessary, palliative care. These actions help complying with the ethical duty of the health care staff by not abandoning the patient, since the fact that the patient does not receive the resources of critical care does not mean that a treatment will be denied to them ((CSG), 2020)

\section{Allocation system of scarce resources in critical care medicine}

Patients with aggravated COVID-19, require an extended intubation of 15 to 20 days through mechanical ventilation (Rosenbaun, 2020). This fact contributes to the scarcity of resources; that is why a two-step allocation system can be established:

1. To assign a prioritization level for each patient, according to the survival probability; this for both confirmed COVID-19 patients and those without the disease but need mechanical ventilation.

2. To periodically evaluate the triage score in patients who are using resources of critical care medicine.

There is no functional situation, prognosis nor validated seriousness of COVID -19 scale yet, where it is established the death probability according to the number of variables, so it is suggested that any intent of allocation of scarce resources between two or more patients is realized based on the following aspects:

a) Current situation (impact of the infection)

b) Previous situation (preexistent comorbidities that have an impact on having the benefit of some treatment)

c) Expectation of survival, according to the infections that the disease generates to the organism ((CSG), 2020).

It is important to let the patient and/or their relatives know that the mechanical ventilation is given temporarily and it will only be given for as long as the triage tam considers necessary, according to the prioritization level ((CSG), 2020).

\section{PRIMARY CASES}

The health care personnel who is tackling the COVID -19 emergency must lead the list to receive the scarce resources of critical care medicine, this exception is realized by considering the following points: as a retribution for its work that made them be exposed to the sanitary risks implied; since they have the main function of combating the epidemic and once they are recovered they can contribute to the situation and finally; if the health care personnel would not have primary attention their labor would be conditioned and would put at risk the attention of the whole population ((CSG), 2020).

\section{ETHICAL RECOMMENDATIONS FOR THE USE OF LIMITED RESOURCES IN THE CRITICAL HEALTH CARE SERVICES, ON BEHALF OF THE PANAMERICAN HEALTH ORGANIZATION (PHO) AND THE WORLD HEALTH ORGANIZATION.}


The PHO together with the WHO, designed a document with a series of recommendations that provide an ethical orientation to guide the actions of the health care personnel before the COVID-19 pandemic situation. These recommendations are:

1. To establish transparent prioritization criteria: to strengthen the trust of people in the health care authorities, which is the key for support and relieves the burden of the health care staff.

2. To save as many lives as possible: basic criterion that implies prioritizing those who are in better clinical conditions to survive to the treatment compared to those who may not recover, even with the treatment. It should be clear that it does not imply the abandonment of the patients; they should receive palliative care if it is not possible to provide them medical treatment.

3. Prioritize those who are in charge of saving the lives of others: people like health care staff who risk their life to save the life of others. They should receive primary attention based on the justice criterion and saving as many lives as possible, since they have a crucial role in assisting others.

4. To treat all people equally: people who are in the same situation (with COVID-19 or other disease), must be treated in the same way. Acting with justice and equity is crucial to guarantee there are no privileges nor discrimination of origin, religion, sexual orientation, economic resources or other criteria apart from these conditions ((OMS) O. P., 2020).

\section{ETHICS OF THE HEALTH CARE PERSONNEL DURING THE PANDEMIC}

If a pandemic is an infectious disease affecting humans throughout a large geographic area (in this case it is a virus: coronavirus) due to a new virus that was previously unknown, this implies that there is no one immune to it and that it is capable of producing serious disease cases and be transferred quickly to people. Then in deed we are facing a big pandemic caused by a virus (coronavirus SARS-COV-2). This way, it seems to come from an animal (zoonosis), and spread from animal to animal, and from animal to people, with a traceability 1:4, which makes it absolutely virulent (exponentially). If there are no measures on time, it causes a collapse of the Health Care Systems and seriously affects the morbimortality of citizens.
In these moments we are facing one of the most serious pandemics in recent history. This implies a global problem that tests global health and the capacity of health care systems and all their staff. This arises important ethical problems that require extraordinary measures demanding even more protocols with very clear scientific evidence.

That is why, when the political criteria are on top of the scientific criteria there is irresponsibility with dramatic consequences as it is happening and continues to happen in this pandemic.

Doing "trial and error" is not very ethical, since it can have very serious consequences on the citizens' lives. Also, the fact of not applying the scientific criteria of a pandemic, as it happened in 8-M (events, uncontrolled airports, religious events, carnivals, sports activities, games) made a biological bomb generating a massive contagion and a viral load for many hundreds of citizens causing and abrupt collapse in the Health Care System with a very high morbimortality.

The main points to ethically distribute medical resources have already been mentioned, when these are exceeded by the amount of patients that need to use them; however, it is also important to carry out a good communication both with the patient and his/her relatives, hoping that the people involved are aware of the risk there might be, for that matter the following ideas are suggested (Iserson, 2020):

1. The health care staff must be the first to share information about the development of the disease, this can help to anticipate to rumors and also reduce the spreading of the disease.

2. To act with precision, since being precise generates credibility, so the given information must include what it is known, what it is not known, and the information that is missing since an incorrect message can lead to harmful behavior and can make people to loose trust.

3. To act with credibility, honesty, punctuality, and according to scientific evidence encourage people to trust in the information and orientation provided.

4. To show empathy; large scale disease outbreaks, like the current COVID-19 pandemic, may generate fear, uncertainty and anxiety. By recognizing people's feelings and their challenges, it is showed that the health care staff is considering people's perspective by giving them accurate recommendations.

5. To promote actions focused on preventing the disease, by generating understanding about the disease, which is a key factor to promote such actions towards stopping the spreading. This must be done through simple messages easy to remember.

6. To communicate respectfully is particularly important when people feel vulnerable; besides, a 
respectful communication promotes cooperation between the public and the health care staff. People's fears and worries must not be forgotten, instead, people must be granted with the opportunity to talk and ask questions, as well as provide them with accurate and concrete information that can help eliminating those behaviors (Iserson, 2020).

\section{CONCLUSION}

The improvement or detriment of someone's health depends on a dynamic process where some factors that are involved make it possible. Therefore, health will not be the process of sickness and recovery, instead, it must be understood as a social component.

Such factors can be economic, cultural, environmental, or even historic factors. From these, the economic factor prevails and determines a benefit or a harm to someone's welfare as it has an influence on the purchasing power of certain goods that can favor a good health, both in preventive, and healing or recovering actions. That is the case of buying medicines, the access to treatments, as well as the incorporation of a healthy lifestyle with the purchase of certain products.

It is important how the economic factor in its less favored sector, meaning, poverty, turn out to be a determinant that forbids the development of optimal levels of health in people. In the first place, it is important to conceive health in a multifactorial sense which includes the conditions around the person and not only his/her physiology or genetics. In second place, identifying the problematic generated by international organisms that turn health in a commodity more than a right; as well as its consequences and repercussions in the medicine field. In the third place, the health spheres in which the lack of economic resources directly influence the acquisition of necessary goods and how this deficiency generates a detriment of individual and collective health, considering that it is even more important during a crisis. Then, there is going to be a discussion around the notion of poverty and its current conceptions for the health field.

Finally, recommendations will be made to rescue a new health model where beneficial or detrimental factors that are external to the individual are considered; as well as the cross-cutting components that must be ensured to improve life quality.

The World Bank, by proposing this privatization of medicine, proposes three fundamental actors to develop health: the individuals and their family at the moment of adopting healthy lifestyles and be in charge of health promotion and recovery; the non-governmental organisms that provide services to those who do not have access to private ones; and finally, private actors who are listed on a stock market.
Suggesting that health is a private subject necessary implies to assume the poverty of a State that cannot deal with the protection of a citizens' human right as it is their life and welfare. That is how the World Bank accepts the poverty of the State without analyzing the destination of resources. The World Bank should analyze more deeply the destination of the public expense and not take for granted that there is no internal economy that can support the most basic protection of the citizens.

The most important thing about the World Bank's proposal is that it leads to the thought of a neutral health, this means going from the social factor as a determinant for health care and conservation, to one that is based on individual care and health private services. In this scheme, it is forgotten that factors such as poverty and hygiene conditions of the social environment are determinant of health.

By considering certain prioritization guidelines when there is scarcity of medical resources, the health care team in charge of medical attention, will not face the hard task of improvising decisions about treatment, and do a proper distribution of the few medical resources at reach and under ethical principles, which also recognizes that the allocation of those resources is transparent and inclusive, and at the same time, make people trust in the general population as well as the medical team.

Due to the above, it is important to highlight that when talking about justice, it is necessary to get past the traditional definitions of common welfare, of the decision about giving each person what is theirs, and other historic ones. It is necessary to conceive justices in its own dimension as a result of harmony between every sphere of a person's life; and such harmony should come from a fulfilment all his/her basic needs on the one hand, and on the other hand, the fact that he/she can have a professional, economic, academic development according to his/her skills, in order to get the highest life quality, in equal conditions regarding the access to and respect of human rights.

In the year 2001, the Committee of Economic, Social and Cultural Rights of the United Nations stated that poverty was: "a human condition characterized by the continuous or chronic deprivation of resources, the capacity, the options, the security, and the necessary power of enjoying a proper lifestyle and other civil, cultural, economic, political, and social rights"

Some problems that increase the incidence of human rights' violation in poor communities are: the cultural conception of women that makes them suffer from attacks, discrimination and violence; the cultural conception of domestic authority that causes psychological, verbal, and physical violence; the harmful cultural practices; the lack of access to education; and the insufficient or non-existent social protection. 


\section{BIBLIOGRAPHY}

(CSG), C. d. (30 de abril de 2020). Guía de Bioética para Asignación de Recursos Limitados de Medicina Crítica en Situación de Emergencia. Obtenido de http://www.csg.gob.mx/descargas/pdf/index/informa cion_relevante/GuiaBioeticaTriaje_30_Abril_2020_7 pm.pdf

(OMS), O. M. (11 de marzo de 2020). Discursos del Director General de la OMS. Obtenido de Alocución de apertura del Director General de la OMS en la rueda de prensa sobre COVID-19 celebrada el 11 de marzo de 202:

https://www.who.int/es/dg/speeches/detail/whodirector-general-s-opening-remarks-at-the-mediabriefing-on-covid-19---11-march-2020

(OMS), O. P. (07 de 05 de 2020). Repositorio Institucional para Intercambio de Información. Obtenido de Orientación ética para el uso de recursos limitados en los servicios críticos de salud durante la pandemia de COVID-19:

https://iris.paho.org/handle/10665.2/52092

(RAE), R. A. (2019). Pandemia. Obtenido de https://dle.rae.es/pandemia

Emanuel, E. J., Persand, G., Upshur, R., Thome, B., \& al, e. (2020). Fair Allocation of Scarce Medical Resourses in the time of Covid-19. N Engl J Med, 2049-2055.

Iserson, K. V. (2020). Healthcare Ethics During Pandemic. West J Emerg Med, 477-483.

Rodríguez-Morales, A, Sánchez-Duque, J., Hernández Botero, S., Pérez Díaz, C., WE, V.-G., \& Méndez, C. y. (2020). Preparación y control de la enfermedad por coronavirus 2019 (COVID-19) en América Latina. Acta Médica Peruana, 3-7.

Rosenbaun, L. (2020). Facing Covid-19 in Italy - Ethics, logistics, and Therapeutics on the Epidemic's Front Line. N Engl J Med.

Solerno, R., Andreatta, P., Ávarez, D., Echellinni, MF, Campodónico, R., . . . Barbero, G. y. (2020). Bioética y pandemia. Revista del Hospital el Cruce, 1-8.

Trilla, A. (2020). One world, one health: The novel coronavirus COVID-19 epidemic. Med Clin (Barc), 175-177.

Zhang, L. a. (2020). Potential interventions for novel coronavirus in China: A systematic review. J Med Virol, 479-490

\section{HAGA CLIC O PULSE AQUÍ PARA ESCRIBIR TEXTO.}

